\title{
Pathogenic post-effect of entomopathogenic fungi on phytophagous pests and entomophagous biocontrol agents
}

\author{
Vladimir Pavlyushin* \\ All-Russian Institute of Plant Protection, sh. Podbelskogo 3, St. Petersburg, Pushkin 196608 Russia
}

\begin{abstract}
Phytosanitary optimization of agricultural ecosystems under conditions of glasshouses and organic farming urgently demands guaranteed effect of plant protection. This can be achieved only through effective exploitation of a complex of biological agents, including arthropod predators and parasites, entomopathogenic fungi, nematodes and other microbes. Entomopathogenic fungi Beauveria bassiana and Lecanicillium muscarium are characterized by facultative parasitism and possess high potential to control phytophagous insects, including pests of vegetable crops in glasshouses. In aphids, fungal pathogenesis was found to be comprised of primary mycosis and toxigenic post-effect in a row of consequent generations. For example, L. muscarium and B. bassiana had an adverse effect on fertility and survival rates of females of aphids Aphis gossypii up to the fifth generation. The longevity, reproductive period and amount of progeny were decreased in aphids treated with water suspension of fungal conidia. It can be deduced that the post-effect is caused by toxic action of metabolites as no evident mycosis was observed in the experiments. Similar type of after-effect is observed in the lacewing Chrysopa carnea contaminated with fungal conidia. The effect is also toxigenic being most prominent in the first generation of the survivors' progeny and traceable up to the fifth generation. The consequences of the infection are best seen in the rate adult emergence which is twice as low as compared to control. This knowledge is essential to avoid antagonism between different groups of natural enemies exploited in biological control and to design adequate technology for their application.
\end{abstract}

\section{Core aspects of biological plant protection}

Phytosanitary optimization of agricultural ecosystems under conditions of glasshouses and organic farming urgently demands guaranteed effect of plant protection. This can be achieved only through effective exploitation of a complex of biological agents, including entomophagous and acariphagous species, entomopathogenic fungi, nematodes and other microbes. Antagonistic bacteria applied as bioformulations with fungicidal [1-3] and bactericidal activity against phytopathogens [4-6] and growth stimulating action towards plants [7-9] are among the key factors of crop protection.

\footnotetext{
* Corresponding author: vapavlyushin@vizr.spb.ru
} 
The success of the parasite complex to limit the number of phytophagous insect pests and other harmful objects is determined by the level of the total biological activity of these elements, including entomopathogenic fungi and bioformulations designed on their basis [10-12]. Technical implementation of the parasite complex is the system of biological plant protection in glasshouses and organic farming [13].

Six core aspects which define the essence of biological protection are as following:

1) phytosanitary monitoring and identification of the parasite complex;

2) anticipatory release of entomophagous biocontrol agents;

3) prophylactic treatments with bioformulations with protective and plant growth regulatory activity;

4) coincidence of optimal temperature and air humidity for protected plants, entomophagous agents and microbial strains;

5) achievement of protective effect due to simultaneous action of a complex of plant protection means against pests and diseases;

6) provocation of depression state of phytophagous insects' populations feeding on resistant crop varieties.

This is therefore highly important to achieve technological compatibility of biological agents. A series of studies demonstrates diverse interactions expressed by pathogens of different groups. Synergism is often observed $[14,15]$ because pathogens typically suppress insect immune system [16] and this favors development of other microorganisms. Mutualistic properties of some insect pathogens have been fixed during evolutionary process, resulting in bacterial-nematode complex formation [17]. This phenomenon is widely exploited in plant protection technologies, including integrated pest management. However, antagonism is also possible due to competition between pathogens for host resources, intoxication by secondary metabolites and other reasons.

The same can be applied to the interactions of entomophagous arthropods and entomopathogens applied simultaneously against a certain pest species. For example, predatory mite Phytoseulus persimilis Athias-Henriot, 1957 and aphid midge Aphidoletes aphidimyza (Rondani, 1847) are refractory to the fungus Beauveria bassiana (Bals.-Criv.) Vuill. 1912 [18]. This makes it possible to combine these arthropods with the pathogen to control insect pests. Predatory and parasitic insects may contribute to dissemination of microorganisms between the phytophagous pests thus facilitation their dispersal [19]. On the other hand, predatory mite Amblyseius swirskii (Athias-Henriot, 1962) was found susceptible to direct spraying with Lecanicillium muscarium R. Zare \& W. Gams, 2001, thus substantiating the neccessity of releasing the mite only after plant treatment with fungal bioformulations [20]. Besides direct action, post-effect of the microbial control agent should also be evaluated both in target insects and useful arthropods, especially those to be applied in combination with the pathogens.

\section{Post-effect of fungi applied against phytophagous pests}

Entomopathogenic fungi B. bassiana and L. muscarium are characterized by facultative parasitism and possess high potential to control phytophagous insects, including pests of vegetable crops in glasshouses [21]. Fungal strains clearly display variability of virulence towards aphids, whiteflies and thrips. Strains with high, medium and low virulence show activity at the rates of about $90 \%, 40-60 \%$, and $30 \%$, respectively. The symptoms of these diseases are also defined by the strain specificity, including melanization and paralysis, and disease development correlates to accumulation of the pathogen biomass within the insect host body. For example, in B. bassiana - Galleria mellonella F., 1798 system, fungal strains have been found causing either generalized, local (at the fungus penetration sites) or no melanization. 
In aphids, fungal pathogenesis was found to be comprised of primary mycosis and toxigenic post-effect in a row of consequent generations. For example, L. muscarium and $B$. bassiana had an adverse effect on fertility and survival rates of females of aphids Aphis gossypii Glov., 1877 up to the fifth generation (Table 1). As compared to the control (untreated aphids), the longevity, reproductive period and amount of progeny were decreased in aphids treated with water suspension of fungal conidia $\left(2.5 \times 10^{7}\right.$ conidia $\left./ \mathrm{mL}\right)$. It can be deduced that the post-effect is caused by toxic action of metabolites as no evident mycosis was observed in the experiments.

Table 1. Post-effect of entomopathogenic fungi Lecanicillium muscarium and Beauveria bassiana on fertility and longevity of Aphis gossypii

\begin{tabular}{|c|c|c|c|c|c|c|}
\hline \multirow{2}{*}{$\begin{array}{c}\text { Fungal } \\
\text { species \& } \\
\text { strain }\end{array}$} & \multicolumn{2}{|c|}{ Indices of I filial aphid generation } & \multicolumn{2}{|c|}{ Indices of V filial aphid generation } \\
\cline { 2 - 7 } & $\begin{array}{c}\text { Longevity, } \\
\text { days }\end{array}$ & $\begin{array}{c}\text { Reproduc- } \\
\text { tive period, } \\
\text { days }\end{array}$ & $\begin{array}{c}\text { Number } \\
\text { of insects } \\
\text { in } \\
\text { progeny }\end{array}$ & $\begin{array}{c}\text { Longevity, } \\
\text { days }\end{array}$ & $\begin{array}{c}\text { Reproduc- } \\
\text { tive period, } \\
\text { days }\end{array}$ & $\begin{array}{c}\text { Number } \\
\text { of insects } \\
\text { in } \\
\text { progeny }\end{array}$ \\
\hline $\begin{array}{c}\text { B. bassiana } \\
\text { K-2 }\end{array}$ & $13,6 \pm 2,62$ & $11,4 \pm 3,1$ & $10,5 \pm 3,2$ & $19,2 \pm 5,2$ & $18,1 \pm 2,1$ & $35,2 \pm 8,2$ \\
\hline $\begin{array}{c}\text { L.muscarium } \\
\text { B-1 }\end{array}$ & $14,0 \pm 3,05$ & $11,2 \pm 3,07$ & $16,0 \pm 6,2$ & $20,4 \pm 2,8$ & $20,1 \pm 3,4$ & $37,1 \pm 6,8$ \\
\hline Control & $19,0 \pm 4,2$ & $17,2 \pm 4,5$ & $36,1 \pm 6,8$ & $21,5 \pm 2,6$ & $20,1 \pm 2,6$ & $49,4 \pm 2,3$ \\
\hline
\end{tabular}

Post-effect is determined in the filial generations of aphids survived after single treatment with fungal conidia suspension. All values in experimental variants are significantly different from control at $\mathrm{p}<0.01$

\section{Post-effect of fungi applied against entomophagous biocontrol agents}

Similar type of after-effect is observed in the lacewing Chrysopa carnea (Stephens, 1836) contaminated with fungal conidia (Table 2). The effect is also toxigenic being most prominent in the first generation of the survivors' progeny and traceable up to the fifth generation.

Table 2. Post-effect of entomopathogenic fungi on the first filial generation of Chrysopa carnea

\begin{tabular}{|c|c|c|c|c|c|}
\hline Fungal species & $\begin{array}{c}\text { Adult } \\
\text { emergence, } \\
\%\end{array}$ & $\begin{array}{c}\text { Adult fertility, } \\
\text { number of } \\
\text { nymphs } \\
\text { produced during } \\
30 \text { days }\end{array}$ & $\begin{array}{c}\text { Voraciousness } \\
\text { of nymphs, } \\
\text { aphids per } \\
\text { nymph }\end{array}$ & $\begin{array}{c}\text { Cocoon } \\
\text { formation, } \\
\%\end{array}$ & $\begin{array}{c}\text { Cocoon } \\
\text { weight, } \\
\text { mg }\end{array}$ \\
\hline $\begin{array}{c}\text { Lecanicillium } \\
\text { muscarium }\end{array}$ & 40 & 23 & 243 & 55 & 5,5 \\
\hline $\begin{array}{c}\text { Beauveria } \\
\text { bassiana }\end{array}$ & 48 & 32 & 214 & 50 & 5,5 \\
\hline $\begin{array}{c}\text { Isaria } \\
\text { fumosorosea }\end{array}$ & 49 & 43 & 228 & 55 & 5,0 \\
\hline Control & 92 & 88 & 257 & 100 & 10,2 \\
\hline
\end{tabular}

The consequences of the infection are best seen in the rate adult emergence which is twice as low as compared to control (untreated lacewings). The adults display a 2-3-fold decrease in fertility as compared to control and teratoid morphology of wings and abdomen. 
In the nymphs of the filial generation, the voraciousness is only slightly decreased. The cocoons of the entomopages are smaller and amount is decreased two-fold as compared to control (Table 2), part of the lacewings also perish within the cocoons. Similar results are obtained for another lacewing species Chrysopa sinica Tjeder, 1936.

Mortality of the predatory insect correlates to the infectious agents' dosage. For example, the dosages of $2.5 \times 10^{7}$ and $2.5 \times 10^{7}$ conidia/mL (which are recommended for phytophagous pest control) caused nymph mortality at the rate of 4-16\%, while overload $\left(4 \times 10^{8}\right.$ conidia/mL) induced $60 \%$ mortality of the aphidophagous agent.

\section{Conclusion}

Comparative analysis of fungal species virulence shows that certain entomophagous species are vulnerable to these pathogens and negative effects can be observed through generations. This knowledge is essential to avoid antagonism between different groups of natural enemies exploited in biological control and design adequate technology for their application. In addition, both species of lacewings are suitable as model objects to study action of microbial formulations on beneficial insects.

\section{References}

1. L. Baffoni, F. Gaggia, N. Dalanaj, A. Prodi, P. Nipoti, A. Pisi, B. Biavati, D. Gioia, BMC Microbiol. 15, 242 (2015) https://doi.org/10.1186/s12866-015-0573-7

2. S. Arunachalam Palaniyandi, S.H. Yang, J.W. Suh, J Microbiol Biotechnol 26(6), 1103-1108 (2016) https://doi.org/10.4014/jmb.1601.01018

3. L. Guardado-Valdivia, E. Tovar-Pérez, A. Chacón-López, U. López-García, P. Gutiérrez-Martínez, A. Stoll, S. Aguilera, Microbiol. Res. 210, 26-32 (2018) https://doi.org/10.1016/j.micres.2018.01.007

4. W. Raza, N. Ling, D. Liu, Z. Wei, Q. Huang, Q. Shen, Microbiol. Res. 192, 103-113 (2016) https://doi.org/437 10.1016/j.micres.2016.05.014

5. T. Ye, T. Zhou, X. Fan, P. Bhatt, L. Zhang, S. Chen, Front. Microbiol. 17(10), 2867 (2019) https://doi.org/10.3389/fmicb.2019.02867

6. T.P. Mamphogoro, O.O. Babalola, O.A. Aiyegoro, J. Appl Microbiol. (2020) https://doi.org/10.1111/jam.14653

7. R. Backer, J.S. Rokem, G. Ilangumaran, J. Lamont, D. Praslickova, E. Ricci, S. Subramanian, D.L. Smith, Front. Plant. Sci. 23(9), $1473 \quad$ (2018) https://doi.org/10.3389/fpls.2018.01473

8. I. Afzal, Z.K. Shinwari, S. Sikandar, S. Shahzad, Microbiol. Res. 221, 36-49 (2019) https://doi.org/10.1016/j.micres.2019.02.001

9. C.M.H. Ferreira, H.M.V.M. Soares, E.V. Soares, Sci. Total. Environ. 10(682), 779799 (2019) https://doi.org/10.1016/j.scitotenv.2019.04.225

10.W. Wakil, M. Yasin, D. Shapiro-Ilan, Sci. Rep. 7(1), 5971 (2017) https://doi.org/10.1038/s41598-017-05615-3

11. S.P. Wraight, M.E. Ramos, J. Invertebr. Pathol. 144, 47-57 (2017) https://doi.org/10.1016/j.jip.2017.01.007

12. S.Q. Tan, Y. Yin, K.L. Cao, X.X. Zhao, X.Y. Wang, Y.X. Zhang, W.P. Shi, Insect Sci. 2020 Mar 13. https://doi.org/10.1111/1744-7917.12776

$\begin{array}{lllll}\text { 13. V.A. Pavlyshin, BIO Web Conf. 18, } 00019 & 0\end{array}$ https://doi.org/10.1051/bioconf/20201800024

14. A.K. Tounou, C. Kooyman, O.K. Douro-Kpindou, H.M. Poehling, J. Invertebr. Pathol. 97(3), 203-210. (2008) https://doi.org/10.1016/j.jip.2007.10.002 
15. Y.S. Tokarev, M.V. Levchenko, A.M. Naumov, I.V. Senderskiy, G.R. Lednev, J. Invertebr. Pathol. 106, 336-338 (2011) https://doi.org/10.1016/j.jip.2010.09.019

16. Y.S. Tokarev. Tsitologiia 58(8), 628-633 (2016)

17. L.G. Danilov, Plant Protection News. 3(97), 38-42 (2018) http://doi.org/10.31993/2308-6459-2018-3(97)-38-42

18. V.Y. Kryukov, N.A. Kryukova, M.V. Tyurin, O.N. Yaroslavtseva, V.V. Glupov, Insect Sci. 25(4), 643-654 (2018) https://doi.org/10.1111/1744-7917.12457

19. G.V. Mitina, L.P. Krasavina, O.V. Trapeznikova, Plant Protection News, 1(99), 18 24. https://doi.org/10.31993/2308-6459-2019-1(99)-18-24

20. G.V. Mitina, E.G. Kozlova, I.M. Pazyuk, Plant Protection News. 2(96), 28-35 (2018) https://doi.org/10.31993/2308-6459-2018-2(96)-28-35

21. G.R. Lednev, V.V. Dolgikh, V.A. Pavlyushin, Plant Protection News, 3, 3-17 (2013) 